\title{
CIVIL SUITS AND CIVIL RIGHTS: RECOVERY OF POLICE EXPENSES
}

The growing militancy of the Negro civil rights movement, bringing with it an increasing number of demonstrations, sit-ins and the like, has presented substantial problems in the development of state regulatory techniques. Having met with a notable lack of success controlling demonstrations through the use of criminal sanctions, ${ }^{1}$ there is now some indication that governmental authorities, ${ }^{2}$ and private citizens $^{3}$ as well, may employ civil suits as a mechanism of control. The counterclaims in Evers v. Birdsong ${ }^{4}$ proffer a unique and potentially effective method for achieving these ends.

Plaintiffs ${ }^{5}$ in Birdsong led a civil rights march to present grievances to the president of Alcorn A. \& M., a predominantly Negro college in Mississippi. The progress of the march along a state highway was barred by State Highway Patrolmen and campus security guards. After refusing to disperse, the group was arrested for disturbing the peace. Plaintiffs then brought a class action seeking injunctive relief, ${ }^{6}$ and the court entered a temporary order permitting the group to march but imposing tight restrictions. ${ }^{7}$ Several weeks later a much larger demonstration was organized which erupted into a full scale riot. The rioting lasted three days, caused considerable damage to the school and also required large numbers of peace officers to restore order. As a result, the head of the Mississippi Highway Patrol and the sheriff of the county where the rioting occurred counterclaimed, ${ }^{8}$ alleging that "it was necessary to call out and keep on duty a sub-

1 See Brown v. Louisiana, 383 U.S. 131 (1966) ; Cox v. Louisiana, 379 U.S. 536 (1965) ; Edwards v. South Carolina, 372 U.S. 229 (1963); Taylor v. Louisiana, 370 U.S. 154 (1962); Garner v. Louisiana, 368 U.S. 157 (1961). But cf. Adderley v. Florida, 35 U.S.L. WEEK 4013 (U.S. Nov. 14, 1966).

2 See Kelly v. Page, 335-F.2d 114 (5th Cir. 1964) (action for injunctive relief).

3 See NAACP v. Overstreet, 221 Ga. 16, 142 S.E.2d 816 (1965), cert. dismissed as improvidently granted, 384 U.S. 118 (1966).

4 Civil No. 1146(W), S.D. Miss., April 5, 1966. As of September 27, 1966, trial had been completed and a district court decision could be expected, judging from plaintiffs' attorney's best guess, in about four months. Letter From Denison Ray, Esq., to the University of Pennsylvania Law Review, Sept. 28, 1966, on file in Biddle Law Library, University of Pennsylvania.

5 Plaintiffs Evers, Russell and Warren are all Negroes and Mississippi residents.

- Suit was brought against the head of the Mississippi State Highway Patrol; the president of Alcorn A. \& M.; the president, vice-president and members of the Board of Trustees of the Institutions of Higher Learning of the State of Mississippi; the head of the Campus Security Patrol; and the sheriffs of two adjacent counties. Defendants were stued both individually and in their official capacities.

7 Plaintiffs and no more than 200 others were to march along the state highway until near the school's administration building, at which point a maximum of four of the leaders were permitted to enter the building and present their grievances. They were then to return to the group, pray and leave. Answer for Defendant, p. 5.

8 The counterclaim raises threshold issues as to the counterclaimants' standing to sue. The head of the Highway Patrol, joined by the state Attorney General, 
stantial number [of their respective peace officers] . . . for the purpose of preserving law and order, as a result of said unlawful conduct on the part of plaintiffs . . . " 9 The Highway Patrol chief and the sheriff both contend that they are entitled to recover expenses incurred in quelling the disturbance and claim damages of $\$ 32,819.75$ and $\$ 2,000$ respectively. ${ }^{10}$ These counterclaims for police expense raise problems as to the existence of such a substantive right, and of more moment, as to constitutional questions involving the civil rights movenent and its demonstrations if such a right is recognized.

\section{The Substantive Right}

The attempt to recover police expenses of keeping law and order and of arresting lawbreakers presents an essentially new problem. Cases involving costs of prosecution offer the closest analogy to the questions raised by the police counterclaim in Birdsong. There exists no common law right to charge costs to the convicted criminal; the state must have statutory authority to tax whatever costs it collects. ${ }^{11}$

brought the counterclaim for the Highway Patrol expenses; the sheriff counterclaimed for his own expenses. To have standing, one must have an interest in the litigation. E.g., Weill v. Weill, 226 Ark. 206, 288 S.W.2d 946 (1956) ; American Book Co. v. Vandiver, 181 Miss. 518, 178 So. 598 (1938) ; Furman Univ. v. Livingston, 244 S.C. 200,136 S.E.2d 254 (1964). "Interest" in this context is interpreted as requiring a pecuniary interest, Furman Univ. v. Livingston, suppra; see Succession of Alstock, $230 \mathrm{La}$. 167, 88 So. 2d 14 (1956), and a suit contesting an abstract principle will not lie. See Weill v. Weill, 226 Ark. 206, 288 S.W.2d 946 (1956). Since the sheriff has a duty to "keep the peace... quell riots ... and unlawful assemblages .. . and to prevent. . . mob violence," Mrss. CoDE ANN. $\$ 4254$ (1956), and since he apparently receives compensation solely from the receipt of fees according to set schedules, Miss. CoDE ANN. $\$ \$ 3928,3937,3952$ (1956); MIss. CoDE ANN. $\$ 3936$ (Supp. 1964), the additional expense occasioned by the riot causes a real outof-pocket loss to the sheriff. Although the sheriff may receive a maximum of $\$ 500$ reimbursement for law enforcement expenses under certain circumstances, MIss. CoDE ANN. $\$ 4171$ (Supp. 1964), he generally is remitted to his fees for these expenses. He would thus appear to have standing. The head of the Highway Patrol presents a different situation. The Highway Patrol is funded through a special fund in the state treasury known as the Highway Patrol Operating Fund. MISs. Cone ANN. $\$ 8120.5$ (1) (Supp. 1964). This fund pays the expenses of "operating and administering the department of public safety, including the highway safety patrol," ibid., and "all unencumbered funds remaining in the ... fund on the last day of each biennium shall be covered into the general fund of the State of Mississippi." MISs. CodE ANN. $\$ 8120.5$ (2) (Supp. 1964). Thus the added expenses flowing from the riot produce a loss only to the general fund of the state, which receives any unexpended appropriations in the patrol operating fund. The head of a patrol and the patrol itself clearly have no pecuniary interest in the matter. Nor can the head of the patrol sue as a taxpayer, for where the wrong is public in nature, it is necessary for the individual to have suffered a special injury. See, e.g., Stietenroth v. Monaghan, 239 Miss. 376, 123 So. $2 d 534$ (1960); cf. Massachusetts v. Mellon, 262 U.S. 447, 488 (1923). Thus the counterclaim of the Highway Patrol chief, in this case at least, should fail at the outset.

8 Answer for Defendant, p. 15. Plaintiffs claim that neither they nor members of their class acted unlawfully, and that plaintiff Evers, the leader of the demonstrations, had at all times advised the demonstrators to act lawfully and nonviolently. Plaintiff's Proposed Findings of Fact and Conclusions of Law, pp. 3-4, 14-22.

10 Answer for Defendant, pp. 15, 16. There was also a counterclaim for property damage to the school brought by the president of the school and the Board of Trustees of the Institutions of Higher Learning of the State of Mississippi.

11 E.g., State v. Jungclaus, 176 Neb. 641, 126 N.W.2d 858 (1964) ; see Melton v. State, 30 Ala. App. 136, 1 So. $2 d 920$ (1941) ; Scholl v. Heumphreus, 136 Kan. 265, 14 P.2d 656 (1932). 
In principle, costs of prosecution cannot be distinguished from the police expenses that are at issue in Birdsong. Both are state expenditures for enforcement of the criminal law. And without a statute specifically authorizing the taxing of given costs, the claims must fail. ${ }^{12}$ The rule would appear to be the same when the recovery of the costs is attempted by civil suit. The only case where an analogous problem was litigated is State Highway \& Pub. Works Comm'n v. Cobb, ${ }^{13}$ which the court described as "admittedly novel in the history of jurisprudence . . . "14 In Cobb, the Highway Commission sued in tort to recover expenses incurred in recapturing defendant, who had escaped from prison. ${ }^{15}$ The court, after distinguishing between criminal and tort actions by stressing the distinction between the state's sovereign and property rights, concluded:

The most that can be said in behalf of the plaintiff is that it is endeavoring to protect public funds given into its custody. These funds were legitimately spent for a public purpose, and there is no statute law, and certainly no common law principle, authorizing their recovery from this defendant. ${ }^{16}$

$C o b b$ has accurately characterized the situation. Since the state may not collect costs by taxing the defendant if there is no specific enabling statute, a different result should not be reached when the state's claim is couched in the form of a civil suit. ${ }^{17}$ The Highway Patrol claim should therefore be denied.

12 See Peters v. State, 9 Ga. 109 (1850) ; Scholl v. Hetumphreus, 136 Kan. 265, 14 P.2d 656 (1932); Commonwealth v. Lesher, 2 Pa. Dist. 859, $13 \mathrm{~Pa}$. County Ct. 462 (C.P. 1893). But cf. State v. Thomson, 188 Kan. 171, 360 P.2d 871 (1961).

13215 N.C. 556,2 S.E.2d 565 (1939).

14 Id. at 557,2 S.E.2d at 566.

15 Plaintiff Commission believed it was significant that the suit was for the expense of recapture, rather than for the original capture of the defendant:

We repeat that the expense incurred is not to be confused with expenses and cost incurred in the original capture of an accused person. This man had been duly convicted, lawfully imprisoned, and he escaped in violation of law, thereby causing the plaintiff to make an expenditure which it would not otherwise have been called upon to make . . . .

Brief for Plaintiff, pp. 4, 5. However, there seems to be no reason to accept this distinction. The criminal's act is equally "in violation of the law" when he commits his original crime, and had he not committed that crime, the state would clearly not have to make "an expenditure which it would not otherwise have been called upon to make . . . ." To permit recovery of expenses only for the crime of escaping, but not for the crime that led to the imprisonment, is hardly reasonable.

18215 N.C. at 559, 2 S.E.2d at 567. (Emphasis added.)

17 Certainly, if it is correct that there is no common law right to tax costs, there should likewise, absent a statute, be no right upon which a civil suit may be based. The reasoning behind the denial of a common law right to tax costs is no doubt grounded upon the type of political theorizing utilized in Cobb:

Since his recapture was a public duty réquired by law under a general system which the State has established, the position of the sovereign towards such a 
The claim of the sheriff raises a somewhat different problem, primarily because he is suing to recover for his own out-of-pocket loss. ${ }^{18}$ However, in view of the common law rule that sheriffs serve gratuitously and the Mississippi scheme for the funding of its sheriffs, his recovery should also be denied. ${ }^{19}$

It is of course within the power of the Mississippi court, or the district court through its interpretation of Mississippi law, to overrule the common law. In this case, however, there is a possible conflict with the ban on ex post facto laws. ${ }^{20}$ Further, if the common law is to

public expenditure can scarcely be that of a private individual who has been compelled to spend money because of the tortious conduct of another. Ibid.

The reasoning in $C o b b$, which can certainly be applied to taxing cases as well, seems to imply that the state, having been created with certain "public duties," should not be taken as having the right to charge its citizens for performing those duties. Only when legislation has so authorized may the state collect for its governmental tasks. See also Ex parte Miller, 97 Okla. Crim. 351, 263 P.2d 522 (1953); Ex parte Coffelt, 93 Okla. Crim. 343, 228 P.2d 199 (1951), where courts refused to uphold statutes in which the costs taxed were for purposes wholly unrelated to the expense of prosecution, holding that such statutes violate constitutional concepts of separation of powers by making the judicial branch a tax collector. The reasoning is tenuous, to say the least, but perhaps it is instructive in throwing further light on the common law bar to the taxation of costs in criminal prosecutions. It is clear that the usual way to finance governmental expenses is through the taxing power, and this power rests solely with the legislature. To permit the executive and judiciary to recover their governmental expenses without authority from the legislature circumvents this principle, and this is true whether it be permitted by a cost-taxing scheme or by civil suit. This of course speaks only to the right of the state to sue in its governmental capacity; it is clear that in its proprietary capacity, "as the owner of property, it may resort to the same tort actions as any individual proprietor to recover for injuries to property ...." PROSSER, TORTS $\$ 2$, at 7 (3d ed. 1964).

18 See note 8 supra.

19 At common law, sheriffs were entitled to no compensation. E.g., Sweat v. Waldon, 123 Fla. 478, 167 So. 363 (1936); Ehlers v. Gallagher, 147 Neb. 97, 22 N.W.2d 396 (1946). Further, the fact that a public officer has a duty to perform certain tasks does not necessarily mean that the law intends to compensate him for them. See, e.g., Northern Ala. Ry. v. Lowery, 3 Ala. App. 511, 57 So. 260 (1911); Ehlers v. Gallagher, supra. In Mississippi, the fees allowed to the sheriff are interpreted as a charge, fixed by statute, for the services rendered by him as a public official. Covington v. Quitman County, 196 Miss. 416, 17 So. $2 d 597$ (1944). The legislative intent has been stated to be that any compensation for additional services is supplied by $\S 4171$ of the Mississippi Code, see note 8 supra, and that other compensation is barred. See Covington v. Quitman County, supra. Thus, to allow the sheriff recovery here would amount to additional compensation for performance of his statutory duties, and this would seemingly violate the intent of the legislature. See ibid.

20 "[A]ny law passed after the commission of the offense for which the defendant is tried inflicting a greater punishment for the act than provided by law at the time the offense was committed, or altering the situation of the accused to his disadvantage, is ex post facto and unconstitutional." United States v. Platt, 31 F. Supp. 788, 792 (S. D. Tex. 1940); see Thompson v. Utah, 170 U.S. 343 (1898). And an "ex post facto effect of a law cannot be evaded by giving a civil form to that which is essentially criminal." Burgess v. Salmon, 97 U.S. 381, 385 (1878) (declaring statute to be ex post facto in suit to collect tax); cf. note 60 infra, discussing the possible characterization of cost-taxing statutes as "penal." The reasoning of these cases indicates that retroactive operation of a statute authorizing cost recovery would violate ex post facto principles; and a new interpretation by a court of an existing statute, operating "precisely like an ex post facto law," would raise valid due process objections. See Bouie v. City of Columbia, 378 U.S. 347, 353 (1964). Overruling of the common law would, however, merely create a new right of action, and the courts' ability to do this in suits between private litigants is unquestioned and may be called for on policy 
be overruled in this situation, a policy argument can be made that the overruling should operate prospectively. ${ }^{21}$

Assuming an enabling statute were passed, however, as it well might be if a legislature whose sympathies were opposed to the civil rights movement thought that the only barrier to the use of this potent weapon ${ }^{22}$ was a lack of statutory authorization, an action for police expenses, either by civil suit or by the taxing of costs, would be maintainable. ${ }^{23}$ There is no question that cost statutes are generally constitutional, ${ }^{24}$ absent specific constitutional defects in a given statute. ${ }^{25}$ Only recently, the Supreme Court of Virginia emphasized the breadth of legislative power to enact cost-taxing statutes:

\section{The General Assembly is the supreme law-making body within} the state of Virginia, and it can enact any law not prohibited by the Constitution of the United States or the Constitution of Virginia . . . . It has not been suggested that the enactment of [the cost-taxing legislation in question]... is prohibited by the Constitution of the United States. . . . The Constitution of Virginia is silent on the subject of costs.

grounds. See, e.g., Warren \& Brandeis, The Right to Privacy, 4 HARv. L. REv. 193 $(1890)$. Here, the action is brought by the state and is attached to a criminal act. Cost statutes have been characterized as penal for the protection of defendants. See note 60 infra. It thus seems reasonable to argue that when a court retroactively adds a system of cost recovery to a criminal act, even if it be by judicial overruling of the common law in a civil suit, it has in effect promulgated an ex post facto law. See Bouie v. City of Columbia, stipra at 353.

Judicial characterization of cost statutes as "penal" does not resolve the issue. The term "penal" does not have an invariant meaning in all contexts; it was employed by these courts only as a shorthand reference for the doctrine that cost-taxing statutes should be narrowly construed, and there is no indication that the term would be applied to ex post facto issues. The state could also contend that the statute is compensatory and thus not a penalty, thereby perhaps obviating due process or ex post facto objections.

Cost taxing differs from a "compensatory" civil suit in an important respect. While the costs assessed might bear no causal relation to the expense occasioned by the defendant's activities, in a civil suit the state would have to demonstrate a causal connection. See note 113 infra and accompanying text. The absence of any causality in a taxing scheme might increase the possibility that the statute would be characterized as penal.

21 The possibility of inflicting a heavy and unexpected judgment by changing the common law is perhaps enough to warrant making the change a prospective one. Cf. Molitor v. Kaneland Community Unit Dist., 18 I11. 2d 11, 163 N.E.2d 89 (1959). See generally Mish kIN \& MoRrIs, ON IAw IN Courrs 293-317 (1965).

22 Other than use as a weapon, the legislature might envision the statute as a justifiable revenue producing technique. See notes 40-42 infra and accompanying text.

23 State Highway \& Pub. Works Comm'n v. Cobb, 215 N.C. 556, 559, 2 S.E.2d 565,567 (1939). (by implication). The Cobb case has been read to stand for the proposition that "the state can never sue in tort in its political or governmental capacity . ..." Prosser, TorTs $\$ 2$, at 7 (3d ed. 1964). While this is perhaps true as a common law principle, the court's language in Cobb clearly implies that if there were a statute, the decision would have been otherwise.

24 E.g., Carter v. City of Norfolk, 206 Va. 872, 147 S.E.2d 139 (1966) ; Kincaid v. Commonwealth, 200 Va. 341, 105 S.E.2d 846 (1958); Jenkins v. State, 22 Wyo: 34, 135 Pac. 749, denying rehearing from 22 Wyo. 34, 134 Pac. 260 (1913).

25 See Rinaldi v. Yeager, 384 Ù.S. 305 (1966) (statute voided as discriminatory); Giaccio v. Pennsylvania, 382 U:S. 399 (1966) (statute permitting cost taxation of an acquitted deferidant voided as lacking sufficient standards). 
It follows . . . that the General Assembly has the authority to provide for the assessment of costs. ${ }^{26}$

If the legislature has the authority to pass a cost-taxing statute covering the police expenses involved in Birdsong, it seems unarguable that it could alternatively enact legislation giving the state or a given state official authority to bring suit for those expenses. Although there is authority indicating that a cost statute can only tax costs that are actually related to expenses of prosecution, ${ }^{27}$ and should not include "the general expense of maintaining the system of courts and the administration of justice, all of which is the ordinary burden of government," 28 it seems that only where the costs are wholly unrelated to the process of arresting and trying the criminal will the courts overturn the statute. ${ }^{29}$ Costs similar to those at issue in Birdsong have been allowed, including expenditures for police, ${ }^{30}$ sheriffs $^{31}$ and arresting officers in general, ${ }^{32}$ except, of course, where not authorized by

26 Carter v. City of Norfolk, 206 Va. 872, 147 S.E.2d 139, 141 (1966).

27 See, e.g., Ex parte Miller, 97 Okla. Crim. 351, 263 P.2d 522 (1953); Ex parte Coffelt, 93 Okla. Crim. 343, 228 P.2d 199 (1951); Ex parte Carson, 143 Tex. Crim. 498, 159 S.W.2d 126 (1942) (alternate holding). But cf. Marquardt v. Fisher, 135 Ore. 256, 295 Pac. 499 (1931).

28 Gleckman v. United States, 80 F.2d 394, 403 (8th Cir. 1935), cert. denied, 279 U.S. 709 (1936) ; see United States v. Murphy, 59 F.2d 734 (S.D. Ala. 1932). But cf. State v. Thomson, 188 Kan. 171, 360 P.2d 871 (1961).

However, the statement in Gleckman may not be as dogmatic as it appears at first glance. The court also notes that "we do not find any authority for holding that such governmental expense can be taxed ... in the absence of statute or established local practice . . . . and in the federal courts, where no federal statute is found to be directly applicable, recourse may sometimes be had to statutes and practices of the state." Gleckman v. United States, stipra at 403. (Emphasis added.) Furthermore, it was in part jury fees and expenses that the court considered to be part of the "expense incurred by the government in providing a tribunal," ibid., and these costs have been recovered pursuant to a statute. See Kincaid v. Commonwealth, 200 Va. 341, 105 S.E.2d 846 (1958) ; cf. State v. Thomson, 188 Kan. 171, 360 P.2d 871 (1961).

29 See Ex parte Miller, 97 Okla. Crim. 351, 263 P.2d 522 (1953) (disallowing costs used for police retirement and pension fund); Ex parte Coffelt, 93 Okla. Crim. 343, 228 P.2d 199 (1951) (disallowing costs used for parole administrative expenses); Ex parte Carson, 143 Tex. Crim. 498, 159 S.W.2d 126 (1942) (disallowing costs used for law library). But cf. Marquardt v. Fisher, 135 Ore. 256, 295 Pac. 499 (1931) (allowing costs for law library taxed on civil litigant).

30 Porterfield v. State, 92 Tenn. 289, 21 S.W. 519 (1893).

31 State v. Williams, 92 Mo. App. 443 (1902).

32 Bell County v. Minton, 239 Ky. 840, 40 S.W.2d 379 (1931) (dictum).

There is at least one key factor distinguishing the recovery attempted in Birdsong from those allowed in the cost-taxing cases. The Birdsong counterclaimants sought a relatively large judgment, running into thousands of dollars. But the costs allowed arresting officers in the past have apparently been limited in amount, often based on fee schedules. In Minton, for example, the officer was allowed to "receive a fee of five dollars to be taxed as costs." Id. at 841,40 S.W.2d at 380 ; see Porterfield v. State, 92 Tenn. 289, 21 S.W. 519 (1893) (fifty dollar allowance). In State v. Williams, 92 Mo. App. 443 (1902), where there apparently was no set maximum, the fees taxed for arrest, travel and taking the prisoner to jail amounted to only $\$ 11.50$. While the type of costs is similar to those sought in Birdsong, the amount is quite different.

Considering the possible penal nature of the assessment of costs, see notes 20 supra and 60 infra, it is conceivable that an excessive charge might run afoul of the 
statute. $^{33}$ While the counterclaims in Birdsong should fail because of the absence of statutory authority, the state could establish a mechanism for recovery of police expenses, if the legislature provides an enabling act.

\section{Constitutional Issues}

It is apparently within the power of the legislature to promulgate statutes permitting recovery of the type of expenses requested in the Birdsong counterclaim. Application of such a statute, particularly to civil rights demonstrations, raises substantial constitutional problems. Although it might well be employed without constitutional objection to collect police expenses from "ordinary" criminals, it is likely that prevailing constitutional doctrines severely limit its application to civil rights demonstrators.

\section{A. The Equal Protection Question}

It seems reasonable to assume that if a statute authorizing the recovery of police expenses is passed in a southern state, the legislature will be motivated largely as a response to the kind of situation found in Birdsong. The real interest of the legislature might well be curtailment of civil rights activities. If such were the case, the statute, either by its language or in its enforcement, probably would attempt to reach only those who participate in civil rights demonstrations which are unlawful at their outset or so become once underway. ${ }^{34}$ This result

eighth amendment prohibition of excessive fines. Though there have been no cases on excessive fines, the Supreme Court has held the eighth amendment's ban on cruel and unusual punishment applicable to the states. See Robinson v. California, 370 U.S. 660 (1962) ; Louisiana ex rel. Francis v. Resweber, 329 U.S. 459, 463 (1947) (dictum). Logically, the ban on excessive fines should also be applicable and Mr. Justice Douglas so stated in NAACP v. Williams, 359 U.S. 550, 551 (1959) (concurring opinion).

Although the courts will invalidate the legislative determination as excessive only in a very clear case, State v. Seraphine, 266 Wis. 118,62 N.W.2d 403 (1954), in some instances the fine has been outrageous enough to warrant judicial action. See Mayor of City of Hoboken v. Bauer, 26 N.J. Misc. 1, 55 A.2d 883 (Recorder's Ct. 1947) (alternative holding), aff'd on other grounds, 137 N.J.L. 327, 59 A.2d 809 (Sup. Ct. 1948) (fine of over $\$ 24,000$ for unlicensed penny bubble-gum machine); State v. Ross, 55 Ore. 450, 104 Pac. 596 (1909), modified, 50 Ore. 474, 106 Pac. 1022 (1910), appeal dismissed, 227 U.S. 150 (1913) (over $\$ 576,000$ fine for larceny). Thus there is a possibility at least that in a given case the police expense charged, if characterized as penal, may be so much greater than the gravity of the offense that the award will be struck down as excessive punishment. It is questionable, however, whether Birdsong itself is such a case, for the charge may not be excessive as related to the plaintiffs' activities.

33 See Peters v. State, 9 Ga. 109 (1850); Commonwealth v. Lesher, 2 Pa. Dist. $859,13 \mathrm{~Pa}$. County Ct. 462 (C.P. 1893).

34 The statute would be unconstitutional if directed at participants in a lawful demonstration, since lawful demonstrations are protected by the first amendment. See notes 69-79 infra and accompanying text.

As used in this Comment, the term "civil rights" signifies the movement for Negro rights. "Demonstration" is used herein to connote all parades, gatherings, marches, etc., regardless of whether they include the element of "opposition" to the prevalent social or political milieu characteristic of civil rights demonstrations. 
could be achieved under four types of statutes: one that permits cost taxation or civil suit only against Negro civil rights demonstrators; one that permits taxation or suit only against civil rights demonstrators; one that permits taxation or suit against all demonstrators; or one that permits taxation or suit against all criminals.

\section{Discrimination in the Drafting of the Statute}

The most blatantly discriminatory type of statute would be the one expressly aimed only at Negro civil rights demonstrators. While there might be a valid rationale for assessing only civil rights demonstrators, ${ }^{35}$ to distinguish between white and Negro civil rights demonstrators solely on racial grounds would clearly be unconstitutional. ${ }^{36}$

Less blatant but still arguably discriminatory on its face would be the second type of statute authorizing recovery of police expense only from civil rights demonstrators. State legislatures are generally granted broad discretion in classifying persons or activities for purposes of regulation and punishment. ${ }^{37}$

Evils in the same field may be of different dimensions and proportions, requiring different remedies. . . . Or the reform may take one step at a time, addressing itself to the phase of the problem which seems most acute to the legislative mind. . . . The legislature may select one phase of one field and apply a remedy there, neglecting the others. . . . The prohibition of the Equal Protection Clause goes no further than the invidious discrimination. ${ }^{38}$

Thus only discrimination that is "invidious" is barred-the classification chosen by the legislature must not be "deliberately based upon an unjustifiable standard such as race, religion, or other arbitrary classification." 39

Whatever the statutory class to be assessed the costs of prosecution "the distinctions that are drawn [must] have "some relevance to the purpose for which the classification is made." "40 In the case of a

35 See notes $40-42$ infra and accompanying text.

38 See, e.g., McLaughlin v. Florida, 379 U.S. 184 (1964). Even under the equal protection test-"invidious discrimination"--traditionally applied in the area of state economic legislation, it is doubtful that this statute would bear a rational relation to a constitutionally permissible objective. See Williamson v. Lee Optical Co., 348 U.S. 483,491 (1955).

37 See, e.g., Ferguson v. Skupra, 372 U.S. 726 (1963); Williamson v. Lee Optical Co., 348 UU.S. 483 (1955).

$38 \mathrm{Id}$. at 489.

39 Oyler v. Boles, 368 U.S. 448,456 (1962). While Oyler is a case involving discriminatory enforcement, see notes 58-60 infra and accompanying text, the requirement of a "justifiable" standard should be equally applicable to the drafting of a statute.

40 Rinaldi v. Yeager, 384 U.S. 305, 309 (1966), quoting Baxstrom v. Herold, 383 U.S. 107, 111 (1966). 
costs statute, the purpose is presumably the reimbursement of the state treasury. "Justifiable," and thus noninvidious, discrimination in a costs statute could involve classification according to the degree of expense caused, and a compelling argument might be made in support of a statute directed against those civil rights demonstrators whose conduct creates police expense. It is quite possible that the costs that flow from an unlawful civil rights demonstration are in general sufficiently great that a state might be justified in focusing its attempts at recovery in that direction. ${ }^{42}$ The state might also advance a second economic justification that, though the costs occasioned by any individual demonstration are not excessive, their ever-increasing number creates a problem of sufficient magnitude to justify special treatment.

Although southern authorities have used various statutes to discriminate against demonstrators merely because they were Negro or favored Negro rights, ${ }^{43}$ it must be recognized that the possibility that high costs are often created by unlawful civil rights demonstrations might give the state added legitimacy of purpose. It is perhaps unfair automatically to cast the southern authorities as the villains, especially in view of the growing tendency within the civil rights movement to disregard the law. ${ }^{44}$ Nonetheless, it is impossible to overlook the danger of the statute's utilization to further anti-Negro aims.

41 See Rinaldi v. Yeager, supra note 40 , at 309.

42 The costs claimed in Birdsong, for example, totalled nearly $\$ 35,000$. It seems unlikely that so large a claim could be made in the usual criminal case. Certain types of crimes, however, frequently may generate police expense of at least as great a magnitude. The expense of manhunts, stake-outs, road blocks, patrols, etc., all of which will often be necessary to apprehend an elusive kidnapper or a mobile bank robber, place those offenses in the same high-cost category as demonstrations. Moreover, it is not clear that civil rights demonstrations necessarily create greater expense than other types of demonstrations. Although there may therefore be some question as to the factual accuracy of a legislative determination that unlawful civil rights demonstrations should be selected for special treatment, the language of the economic equal protection cases such as Lee Optical, see text accompanying note 38 supra, indicates that this determination might nonetheless be within the legislature's discretion.

43 See Shuttlesworth v. City of Birmingham, 180 So. 2d 114 (Ala. App. 1965) (alternate holding). Although the court in Shuttlesworth did not mention that the discrimination concerned Negroes or Negro rights, defendant Shuttlesworth was both a Negro and active in the civil rights movement, see Shuttlesworth v. Gaylord, 202 F. Supp. 59 (S.D. Ala. 1961), aff'd sub nom. Hanes v. Shuttlesworth, 310 F.2d 303 (5th Cir. 1962), and the implication is clear that the pattern of enforcement held objectionable was directed at Negroes.

44 One columnist, who could scarcely be characterized as sympathetic with anticivil rights authorities, has noted that the apparently "rising tide of Negro extremism" has created "a genuine belief that the Negro struggle has passed from promise to threat and is beginning to defeat itself." Wicker, Public Opinion and the Filibuster, N.Y. Times, Sept. 14, 1966, p. 46, col. 5. A sampling of news items from the previous day lends weight to this belief:

Atlanta, Ga.-The outburst [of violence] . . . came after a meeting . . . where leaders from the Southern Christian Leadership Conference and the Student Non-violent Coordinating Committee vied for a following. . . . At the meeting, Hosea Williams, political action director of the SCLC, was shouted down with cries "black power" ....

Many of the youths wore orange sweat shirts bearing a facsimile of a black panther, the rallying symbol of "black power" advocates. SNCC 
This type of statute avoids the most blatant form of racial discrimination, since it applies equally to all civil rights demonstrators, whether Negro or white. ${ }^{45}$ But the apparent equality is only an illusion, since the statute applies only to persons endeavoring to champion the rights of a specific racial group. Because of this underlying discrimination, the statute would still come within the rubrics established for testing racial classifications, ${ }^{46}$ even though whites as well as Negroes are subject to suit for police expenses. A state should not be able to use a purported economic justification as a sham to implement a policy of racial discrimination. ${ }^{47}$ Furthermore, the broad discretion allowed the legislature in enacting discriminatory measures in the commercial area is narrowed "when legislation appears on its face to be within a specific prohibition of the Constitution ... ." 48 This is especially true of racial classifications

which must be viewed in light of the historical fact that the central purpose of the Fourteenth Amendment was to eliminate racial discrimination emanating from official sources in the States. This strong policy renders racial classifications "constitutionally suspect" . . . and "in most circumstances irrelevant" to any constitutionally acceptable legislative purpose.... ${ }^{48}$

[L] egislative discretion to employ the piecemeal approach [to solve general evils] stops short of permitting a State to narrow statutory coverage to focus on a racial group. Such classifications bear a far heavier burden of justification. ${ }^{50}$

workers waved signs which read, "Move on Over or We'll Move on Over You."

Bogalusa, La_-Negroes last night voted to defy a city ordinance and stage a protest march tonight. . . . [The Bogalusa Civic and Voters] League president A. Z. Young told the approximately 200 Negroes: "When you get some money, don't spend it on wine, get a gun."

Philadelphia Evening Bulletin, Sept. 13, 1966, p. 3, cols. 1-3.

This is not to say that the civil rights movement may not continue to have legitimate grievances. The Bogalusa demonstration, for example, was motivated by a belief that "the only reason for the law was to prevent demonstrations during the only time Negroes are free from employment obligations." Id. col. 2 . But the means utilized to present those grievances may well run counter to the demands of an orderly society.

45 See note 36 supra and accompanying text.

46 See text accompanying notes 48-51 infra.

47 What may on its face be a valid purpose for a statute cannot be "used as a cloak to discriminate against one class or group." Gray v. Sanders, 372 U.S. 368, 379 (1963) (dictum). See also Barrows v. Jackson, 346 U.S. 249 (1953).

48 United States v. Carolene Prods. Co., 304 U.S. 144, 152 n.4 (1938).

49 McLaughlin v. Florida, 379 U.S. 184, 192 (1964).

50 Id. at 194. 
Such a law . . . will be upheld only if it is necessary, and not merely rationally related, to the accomplishment of a permissible state policy. ${ }^{51}$

The state thus must bear a weighty burden of proof to sustain a statute based on a racial classification ${ }^{\mathbf{5 2}}$ such as the one envisioned here, and it is unlikely such a burden could be sustained.

A somewhat more subtle method of drafting a discriminatory classification could also be utilized. It is possible that, in view of the growing sophistication of state legislatures, a statute might be drafted which is nondiscriminatory on its face, but which in effect applies only against civil rights demonstrators. An example of this technique is the following Oklahoma constitutional provision:

No person shall be registered as an elector of this State or be allowed to vote in any election held herein, unless he be able to read and write any section of the constitution of the State of Oklahoma but no person who was, on January 1 , 1866 , or at any time prior thereto, entitled to vote under any form of government, or who at that time resided in some foreign nation, and no lineal descendant of such person, shall be denied the right to register and vote because of his inability to so read and write sections of such constitution..$^{53}$

This provision is at first blush nondiscriminatory. But the Supreme Court held that the effect of this "grandfather clause" was to deprive Negro citizens of the right to vote in violation of the fifteenth amendment. ${ }^{54}$ The date employed in the statute was prior to the ratification of the fifteenth amendment; the effect of the standards, thongh not expressed as such, was to deny the vote because of race, color or previous condition of servitude. In the area of recovery of police expenses, the courts should be equally ready to discern and strike down legislative attempts to mask racial discrimination.

\section{Discrimination in the Enforcement of the Statute}

A statute authorizing recovery of police expense from all unlawful demonstrators, or from all criminals, would on its face be valid. ${ }^{55}$ Equal protection problems would arise, however, if the statute, though broadly drafted and nondiscriminatory on its face, were enforced on the basis of a racial classification. This question is raised in Yick $W o$

51 Id. at 196.

52 See text accompanying notes $45-47$ supra.

53 Okra. Const. art. III, \$ 4 a.

54 Guinn v. United States, 238 U.S. 347 (1915).

55 The "discrimination" entailed in directing the statute only at demonstrators could perhaps be justified on economic grounds. See notes $40-42$ supra and accompanying text. Since there would be no racial classification involved, the legislature could safely treat only part of the "evil." See text accompanying notes 37-38 supra. $B u t$ cf. notes 64-138 infra and accompanying text, discussing first amendment problems. 
v. Hopkins.58 Petitioner, operator of a Chinese laundry, was convicted of conducting his business in violation of a city ordinance requiring a permit to house a laundry in a building made of wood. A permit had been applied for, but it had been denied, and petitioner demonstrated that the ordinance was used to deny permits to launderers of Chinese descent, while white operators were permitted to utilize wooden buildings. The Court, in granting habeas corpus, stated:

$[T]$ he cases present the ordinance in actual operation, and the facts shown establish an administration so exclusively against a particular class of persons as to warrant and require the conclusion that, whatever may have been the intent of the ordinances as adopted, they are applied . . . with a mind so unequal and oppressive as to amount to a practical denial by the State of that equal protection of the laws which is secured [by] . . . the Fourteenth Amendment. . . . Though the law itself be fair on its face, and impartial in appearance, yet, if it is applied and administered by public authority with an evil eye and unequal hand, so as practically to make unjust and illegal discriminations . . . the denial of equal justice is still within the prohibition of the Constitution. ${ }^{57}$

The considerations which are involved in determining the validity of selective enforcement should not be different from those used to evaluate discriminatory classification in drafting. There is a range of permissible discretion in selective enforcement, and it is the type of standard used to determine the selectivity that controls constitutionality of the exercise of that discretion. The Supreme Court, in Oyler v. Boles, 58 a case involving alleged discriminatory application of West Virginia's recidivist statute, ${ }^{\text {t9 }}$ insisted:

[T] he conscious exercise of some selectivity in enforcement is not in itself a federal constitutional violation. . . . [I]t was deliberately not stated that the selection was based upon an unjustifiable standard such as race, religion, or other arbitrary classification. Therefore grounds supporting a finding of denial of equal protection are not alleged. ${ }^{60}$

56118 U.S. 356 (1886).

57 Id. at 373-74.

58368 U.S. 448 (1962).

69 W. VA. CODE ANN. $\$ 6131$ (1961).

60368 U.S. at 456 . (Emphasis added.)

Oyler also bears on a related problem: whether the Yick Wo reasoning is applicable to penal statutes. The general rule is that cost statutes are penal. E.g., Shackleford v. State, 204 Ala. 362, 85 So. 786 (1920); Cramer v. Smith, 350 Mo. 736, 168 S.W.2d 1039 (1943); State v. Faulkner, 75 Wyo. 104, 292 P.2d 1045 (1956). But cf. Kincaid v. Commonwealth, 200 Va. 341, 105 S.E.2d 846 (1958) (by implica- 
While state authorities who enforce a police expense recovery statute only against civil rights demonstrators could perhaps base their selectivity on the degree of expense caused, ${ }^{61}$ the exercise of this selectivity should be faced with the same rigid standards as apply to legislation employing a racial classification. ${ }^{62}$ Simply, if a legislature is to overcome equal protection problems, its statute must be drafted to cover all unlawful demonstrators and must not be applied for the purpose of racial discrimination. ${ }^{63}$

tion); Anglea v. Commonwealth, 51 Va. (10 Gratt.) 696 (1853). And if a statute taxing costs is penal, it can be conceded for these purposes that a statute authorizing the recovery of police expenses by civil suit would also be so characterized. See note 20 sipra.

Courts have reasoned that the $Y i c k$ Wo rule is not applicable to penal statutes. See, e.g., Society of Good Neighbors v. Mayor of Detroit, 324 Mich. 22, 36 N.W.2d 308 (1949). The case is criticized in Note, 59 YALE L.J. 354 (1950), and this reasoning is certainly questionable, see Comment, 61 Cor.um. L. REv. 1103 (1961) ; Note, 59 Y ALE L.J. 354 (1950). In any event the language in Oyler clearly indicates that the Court will not tolerate "unjustifiable" discriminatory enforcement of penal statutes. See The Supreme Court, 1961 Term, 76 Harv. L. Rev. 54, 121-22 (1962).

(At least one writer has questioned how "conscious selectivity" can ever be used without discrimination. 24 U. PrTT. L. REv. 185, 187 (1962). Logically, all enforcement demands at least some selectivity; the Court, however, appears to be distinguishing between discrimination for constitutionally valid and invalid purposes.)

61 See notes 40-42 supra and accompanying text.

62 Prosecutors would not be barred from exercising discretion in areas where it has traditionally been permitted. Certainly they should not be required to attempt cost recovery where the amount involved would not justify the effort. Cf. Swain v. Alabama, 380 U.S. 202, 220 (1965) (discretionary enforcement with racial overtones permitted because of the "essential nature" of the system of peremptory challenges). But cf. Rinaldi v. Yeager, 384 U.S. 305 (1966) (rejecting state's financial justification argument to void as discriminatory a statute taxing costs for transcript only from imprisoned criminals). Nor should prosecutors be required to institute suit in every case where enough money is involved to warrant the attempt. $C f$. Oyler v. Boles, 368 U.S. 448 (1962). This exercise of discretion is related to another problem-the burden of proving "discrimination." See note 63 infra.

63 While the state will need to justify any discriminatory enforcement, the burden of initially proving that discriminatory enforcement exists falls to the defendant. See Swain v. Alabama, 380 U.S. 202, 209 (1965). Where a statute is discriminatory on its face, this presents little problem; but proving that an otherwise valid statute is discriminatorily enforced can be more difficult. Other than Yick $W o$, in cases where both discriminatory application and overbroadness were alleged, the Court has invalidated the statute on the latter ground. See, e.g., Hague v. CIO, 307 U.S. 496 (1939); cf. Niemotko v. Maryland, 340 U.S. 268 (1951). Further, the evidence of discrimination has been unquestionable. Ibid. If there is a clear pattern of discriminatory enforcement over a period of time, proof may not be difficult. If the statute is not utilized for several years after its passage and is then for the first time applied against civil rights demonstrators, discrimination will be more difficult to demonstrate. If the statute is passed and is then utilized initially within a short time thereafter against a civil rights group, a claim of discriminatory enforcement may be unprovable. However, the possibility of demonstrating discriminatory enforcement would be enhanced if either during the process of enactment or application state legislators or officials disclose a discriminatory purpose.

The cases where there is a suspicion of discrimination, without an absolute and clear pattern, present the greatest problem of proof. It is possible, however, that even without a clear "prior restraint," where the discrimination threatens personal liberties in any manner, the Court will more closely scrutinize both the classification chosen by the legislature and the statute's application than it does in the economic area. Cf. Rinaldi v. Yeager, 384 U.S. 305 (1966). Compare Skinner v. Oklahoma, 316 U.S. 535 (1942), with Williamson v. Lee Optical Co., 348 U.S. 483 (1955). 


\section{B. Reluctance To Demonstrate and "Breathing Space": ${ }^{64}$}

\section{The First Amendment Question}

Apart from the problem of discrimination, a statute that authorizes recovery of police expenses resulting from demonstrations may raise first amendment problems when applied to persons whose conduct, at least at the inception of the demonstration, is lawful. In discussing a possible infringement of constitutionally protected rights, it must be noted at the outset that first amendment freedoms do not exist in a vacuum; every given fact situation presenting a first amendment issue must be resolved by balancing the right against the state's interests, implicit in which may be the need to limit the protected freedom. ${ }^{65}$ Statutory control limiting freedom in this area should occur, however, only with good reason, and if the public interest is not weighty, infringement should be barred. ${ }^{66}$ "[I]t is the character of the right . . . which determines what standard governs the choice." 67 The rights in question, when used for a political or social purpose, are given special protection. ${ }^{.8}$

\section{Constitutionally Protected Conduct}

The balancing process focuses on who can be held liable for a given type of conduct and what weight is to be given to the preservation of first amendment rights when balanced against the state's interests in deterring an illegal demonstration, recovering the costs, or both. At one extreme is the demonstrator who is in all respects peaceful and

64 NAACP v. Button, 371 U.S. 415, 433 (1963).

65 The most oft-used example of this balancing process is the man Mr. Justice Holmes envisioned as shouting "fire" in a crowded theater. See Schenck v. United States, 249 U.S. 47 (1919). More recently the rule has been stated thusly: "In each case . . [the courts] must ask whether the gravity of the 'evil,' discounted by its improbability, justifies such invasion of free speech as is necessary to avoid the danger." United States v. Dennis, 183 F.2d 201, 212 (2d Cir. 1950) (I. Hand, J.), aff'd, 341 U.S. 494 (1951).

${ }^{66}$ See Thomas v. Collins, 323 U.S. 516, 530 (1945) :

[A]ny attempt to restrict those liberties must be justified by clear public interest, threatened not doubtfully or remotely, but by clear and present danger. The rational connection between the remedy provided and the evil to be curbed, which in other contexts might support legislation against attack on due process grounds, will not suffice. These rights rest on firmer foundation. Accordingly, whatever occasion would restrain orderly discussion and persuasion, at appropriate time and place, must have clear support in public danger, actual or impending. Only the gravest abuses, endangering paramount interests, give occasion for permissible limitation. It is therefore in our tradition to allow the widest room for discussion, the narrowest range for restriction, particularly when this right is exercised in conjunction with peaceable assembly.

More recently, it has been suggested that the "necessary . . . to the accomplishment of a permissible state policy" test applied to racial discrimination in McLaughlin, see text accompanying note 51 supra, will be used in all cases where "fundamental personal liberties are involved." See Griswold v. Connecticut, 381 U.S. 479, 497 (1965) (Goldberg, J., concurring).

67 Thomas v. Collins, supra note 66, at 530.

68 Compare DeJonge v. Oregon, 299 U.S. 353, 364-65 (1937), with United States

v. Carolene Prods. Co., 304 U.S. 144, 152-54 (1938). 
lawful; his is a demonstration that is unquestionably within the protection of the first and fourteenth amendments. ${ }^{69}$ A statute prohibiting such conduct would unquestionably be void; ${ }^{70}$ an attempt by the state to deter the use of these rights would be unconstitutional. But what of a civil suit, authorized by statute where necessary (as in Birdsong), permitting recovery of damages flowing from the demonstrations, lawful though they may be? When a demonstration takes place in a charged atmosphere, police must often be present to maintain order. The state's interest may not be deterrence of the demonstration, but merely recovery of the expenses of the demonstration from those who caused the expenditure. Although demonstrations protected by the first amendment are entitled to police protection, ${ }^{71}$ may the police recover from the demonstrators who, no matter how well behaved, have by the mere act of demonstrating caused the police to incur expense?

It does not necessarily follow that simply because the right is constitutionally protected, there is an absolute bar to charging for its use. Under a valid statute, it is permissible to require a parade permit in the interests of order, traffic control, etc., ${ }^{72}$ and it is also permissible to exact a reasonable fee for the permit, with the amount of police protection necessitated a relevant factor in determining reasonableness. $^{73}$ But a fee, even a flexible one, has a ceiling, ${ }^{74}$ and the cases concerning parade permit fees do not suggest that they could cover all police expense. Rather, the state has a constitutional duty to provide a forum for the exercise of first amendment rights. ${ }^{75}$ The public interest justifies the collection of no more than a nominal ${ }^{76}$ fee

69 Peaceful picketing is "not to be abridged by arrest or other interference so long as asserted within the limits of not unreasonably interfering with the rights of long as asserted within the Page, 335 F.2d 114, 119 (5th Cir. 1964); see Edwards v. South Carolina, 372 U.S. 229 (1963).

70 See Thornhill v. Alabama, 310 U.S. 88 (1940); cf. Edwards v. South Carolina, 372 U.S. 229 (1963); Murdock v. Pennsylvania, 319 UU.S. 105 (1943).

71 Kelly v. Page, 335 F.2d 114, 119 (5th Cir. 1964) (dictum).

72 The question of validity of statutes of this type has generally centered upon whether the statutes permitted arbitrary discretion in the granting of permits by local whethorities. See Shuttlesworth v. City of Birmingham, 180 So. 2d 114 (Ala. App. 1965); cf. Niemotko v. Maryland, 340 U.S. 268 (1951).

73 See Cox v. New Hampshire, 312 U.S. 569, 576-77 (1941).

74 In Cox, for example, the maximum fee permissible was $\$ 300$. Id. at 571-72 n.1.

75 See Kalven, The Concept of the Public Forum: Cox v. Lonisiana, in 1965 THE Supreme Court Review 1 (Kurland ed. 1965); cf. Grosjean v. American Press Co., 297 U.S. 233 (1936).

76 See Murdock v. Pennsylvania, 319 U.S. 105 (1943). In Murdock, the city attempted to recover a fee under a canvassing and soliciting ordinance from Jehovah's Witnesses who went from door to door soliciting purchases of books published by the religious society. The Court held this to be "in substance" a "tax laid specifically on the exercise" of first amendment freedoms, and therefore unconstitutional. Id. at 108. The fee in Cox was upheld because it was designed to "protect and insure the 
to help defray the costs of the demonstration. ${ }^{77}$ This is especially true in view of the high priority accorded first amendment freedoms when employed in a political or social context, balanced against the fact that collection of the fee is more a convenience than a necessity, since the state's taxing power allows it to recoup its expenses even without the fee. The burden on the whole of the taxpaying public would then be relatively small, and would in no way impede the use of constitutionally protected rights.

The fact that a potentially large charge would not be assessed until after the demonstration (whereas a permit fee would be established and paid beforehand) creates an additional problem. The demonstrator would never know how great his charge would be until the demonstration ended, and the fear that it might be prohibitive could discourage him from demonstrating at all. ${ }^{78}$ Given the constitutional protection of peaceful demonstrations, the charge made must be small enough so that the necessity of payment will not deter the use of the freedom to demonstrate. And a civil suit, actually an attempt at recovery in the nature of damages for the complete expense, would likely be so great as to stifle the exercise of first amendment rights. ${ }^{79}$

safety, comfort, or convenience of the public" and was "a nominal one imposed as a regulatory measure..." Id. at 116. The implication is clear-although in a parade/demonstration situation fees are not barred, where a threat to first amendment freedoms exists it will be closely scrutinized as to amount and effect.

77 See note 73 supra and accompanying text.

78 The fact that the amount of a jury verdict is uncertain would be a major factor deterring a potential demonstrator. In addition, a court passing on the constitutionality of an expense recovery statute might consider the wide discretion granted the jury in assessing damages, with the attendant potential for discrimination, as one of the factors militating against the constitutionality of the statute. $C f$. Poulous v. New Hampshire, 345 U.S. 395, 405-08 (1953) (dictum) (administrative discretion in parade licenses). See note 72 stupra.

79 It is also possible that recovery in these circumstances might be attempted under a cost-taxing statute. The reasons for striking the balance in favor of the first amendment rights are no less compelling here. Further, since we must assume that if brought to trial, the peaceful demonstrators would be acquitted (their convictions could not constitutionally stand), see Edwards v. South Carolina, 372 U.S. 229 (1963), the costs should not be allowed.

It is not settled that there is an absolute bar to taxing costs on an acquitted defendant. In Giaccio v. Pennsylvania, 382 U.S. 399 (1966), defendant challenged a statute that provided:

In all cases of acquittals [for offenses other than felonies] . . . the jury shall

determine, by their verdict, whether the county, or the prosecutor, or the defendant shall pay the costs ....

Pa. Stat. AnN. tit. 19, §1222 (1964).

The court invalidated the statute for neither it nor the interpretation given to it by the state courts, requiring "misconduct" or "reprehensible conduct," contained sufficient standards to prepare a defense. Giaccio v. Pennsylvania, stipra at 404 . While two members of the Court did believe that taxing costs on an acquitted defendant was itself a denial of due process, $i d$. at 405 (concurring opinions of Stewart, J. and Fortas, J.), this has not been decided definitively. The morality of charging the acquitted defendant is also questionable; it has been suggested that when a defendant is acquitted, a "fair-minded" state will pay his costs. CAEN, THE PREDICAMrEnT of Dexrocratic Man 51-52 (1961). Since the first amendment principles applicable to civil suits should also apply to cost-taxing measures, see notes 13-17 supra and accompanying text, cost taxing of an acquitted demonstrator would be unconstitutional. 


\section{Constitutionally Unprotected Conduct}

The peaceful demonstrator must be contrasted with the demonstrator who acts unlawfully. ${ }^{80}$ Freedom of expression and assembly must be balanced against the need for public order, ${ }^{81}$ and the right of freedom of assembly can in no way include unlawful behavior. The state's interest goes beyond recovering its expenses; it also may validly attempt to protect its citizens ${ }^{82}$ by deterring unlaweful conduct. However, this analysis does not conclude the problem. Though it might appear constitutionally safe to permit recovery only against demonstrators convicted ${ }^{83}$ of participating in unlawful conduct, even this rule can work substantial deterrence to the use of first amendment rights.

Although there is no question that the state has a great interest in deterring unlawful acts through its criminal law, its interests in recovering police expenses are not so great. ${ }^{84}$ Of course an individual can claim no constitutional right to break the law; but the problem of deterrence occurs because successful civil recovery from the rioter may act to prevent the lawful demonstrator from exercising his right to demonstrate. The central and unavoidable difficulty is that the extent of recovery is indefinite, potentially limitless and determined after the fact. ${ }^{85}$

This problem becomes critical because many of the deterrent effects inherent in criminal prosecutions are applicable to suits for recovery of police expenses. A demonstrator may fear that he will be adjudged to have acted unlawfully even though he had not.

80 In discussing rioters or other unlawful demonstrators, this Comment assumes that these individuals started out as part of a peaceful demonstration, which at its inception had first amendment protection. The thrust of the discussion of first amendment deterrence is not applicable to a riot that commenced with an unlawful act. Concretely, concepts of first amendment deterrence would not protect a riot or other unlawful acts which, for example, were a reaction to an attempt to resist arrest.

The term "unlawful" refers only to conduct prohibited by a statute which, apart from any costs provision, is constitutionally valid.

81 See, e.g., Feiner v. New York, 340 U.S. 315 (1951); Cox v. New Hampshire, 312 U.S. 569 (1941); cf. Adderley v. Florida, 35 U.S.L. WEEK 4013 (U.S. Nov. 14, 1966).

82 See, e.g., Kovacs v. Cooper, 336 U.S. 77 (1949); Chaplinsky v. New Hampshire, 315 U.S. 568 (1942).

83 See note 80 supra and accompanying text. But cf. notes 98-99 infra and accompanying text. Tangential problems remain. Unprotected conduct may be constitutionally unpunishable where a statute is overly broad, or vague. See notes 101-02 infra. Thus a conviction may be reversed because of a defective statute, and defendant will not be subject to cost recovery. But query: if defendant during his conviction proceedings does not assert that the statute is constitutionally defective, can he later contest the same issue in the suit for costs? If the statute is overturned in another case before the cost suit is brought, can defendant use the judgment of unconstitutionality as a defense in his cost suit? This Pandora's box of procedural difficulties is beyond the scope of this Comment.

84 See notes 91-92 infra and accompanying text.

85 See note 78 supra and accompanying text. 
"Unlawful" is a word that is no more than conclusory; the demonstrator who desires to conduct himself lawfully may not be certain exactly how far his first amendment protection extends, and in given circumstances even apparently lawful and protected acts may be characterized as unlawful and unprotected. ${ }^{86}$ Further, while the general requirement of specificity in defining criminal offenses ${ }^{87}$ provides some protection, the demonstrator may still be faced with the distinct possibility that the state will be able to produce sufficient evidence before perhaps hostile ${ }^{88}$ fact finders to secure a conviction which can withstand review. This is especially true if the suit for police expense recovery is not premised upon a criminal conviction but rather the determination that the demonstrators acted unlawfully is made under civil procedural rules. Added to this is the possibility that civil liability may stretch beyond the causative effects of defendant's acts, ${ }^{89}$ and these factors in combination may well result in a decision not to demonstrate. ${ }^{80}$

Though the state has an interest in protecting its citizens through criminal penalties for unlawful acts, ${ }^{91}$ when the potency of this package of deterrents is balanced against the state's lesser interest in recovering police expenses, ${ }^{92}$ recovery should be barred, unless the deterrents can

86 The characterization of a lawful act as one protected under the first amendment does not necessarily draw a sharp line. See Garner v. Louisiana, 368 U.S. 157, 207 (1961) (Harlan, J. concurring) ; cf. Note, 109 U. PA. L. REv. 67, 99-104 (1960). Compare Adderley v. Florida, 35 'U.S.L. WeEk 4013 (Nov. 14, 1966) (demonstration ruled unprotected because held on jail grounds); Feiner v. New York, 340 U.S. 315 (1951) (defendant's arrest resulting from the conduct and reaction of the crowd to whom he was speaking held valid).

87 See generally Note, 109 U. PA. L. REv. 67 (1960).

88 See New York Times Co. v. Sullivan, 376 U.S. 254, 293-97 (1964) (Black, J., concurring).

One of the acute and highly emotional issues in this country arises out of efforts of many people. - . to continue state-commanded segregation of races . . . The scarcity of testimony to show that Commissioner Sullivan suffered any actual damages at all suggests that these feelings of hostility [toward those favoring desegregation] had at least as much to do with rendition of this half-million-dollar verdict as did an appraisal of damages.

Id. at 294.

89 See note 113 infra and accompanying text.

90 This is perhaps the essence of the "breathing space" concept; breathing space is necessary to limit "indirect" infringement of unarguably protected rights. Statutes that are vague, for example, "have a coercive effect since rather than chance prosecution people will tend to leave utterances unsaid even though they are protected by the Constitution." Collings, Unconstitutional Uncertainty-An Appraisal, 40 CoRNELL L.Q. 195,219 (1955).

01 The state's right "to impose regulations in order to assure the safety and convenience of the people in the use of public highways has never been regarded as inconsistent with civil liberties but rather as one of the means of safeguarding the good order upon which they ultimately depend." Cox v. New Hampshire, 312 U.S. 569,574 (1941). Riotous conduct clearly is violative of safety and "good order," and where such a threat was present, the Court has at times sharply curtailed first amendment protection. See Feiner v. New York, 340 U.S. 315 (1951).

92 Presumably, the civil suit for police expenses will be designed to reimburse the state treasury rather than distribute the costs of the demonstration through taxation. The Supreme Court has made this assumption in a case involving a statute which provided for collection of the cost of a transcript from a prisoner. See Rinaldi v. Yeager, 384 U.S. 505, 509 (1966). If the state desires to increase the deterrent to riots, the appropriate mechanism would seem to be an increase in criminal penalties. 
be minimized so that the individual will feel free to proceed with a peaceful demonstration. In some situations, otherwise "unlawful" conduct may need to be protected when first amendment deterrence is involved. The reasoning of the Supreme Court in New York Times Co. v. Sullivan ${ }^{93}$ provides an illustration. The Court there decided that defamatory statements concerning public officials in their official capacity were not actionable without a showing of actual malice. The Court reasoned:

The judgment awarded in this case . . . was one thousand times greater than the maximum fine [for criminal defamation] . . . Whether or not a newspaper can survive a succession of such judgments, the pall of fear and timidity imposed upon those who would give voice to public criticism is an atmosphere in which the First Amendment freedoms cannot survive. . .

A rule compelling the critic of official conduct to guarantee the truth of all his factual assertions . . . does not mean that only false speech will be deterred. . . . Under such a rule, would-be critics of official conduct may be deterred from voicing their criticism, even though it is believed to be true... . The rule thus dampens the vigor and limits the variety of public debate. It is inconsistent with the First and Fourteenth Amendments. ${ }^{94}$

The Court has, in effect, protected first amendment liberties by insulating conduct previously considered one step beyond those rights. Although the ordinary rules of defamation dictate that the state has a reasonable justification for curbing defamatory publication in the interest of protecting its citizens, Sullivan represents a judgment that there was an absence of conduct "endangering paramount interests." ${ }^{5}$ To guarantee the right of free expression and criticism, it becomes necessary to establish a privileged category of defamation. ${ }^{96}$ The Court has clearly chosen to strike the balance ${ }^{97}$ well on the side of first amendment liberties.

93376 U.S. 254 (1964).

$94 I d$. at 277-79. (Emphasis added.)

95 See note 66 supra.

96 The court's recognition that fear can constrict protected rights as substantially as actual suppression is reminiscent of the vagueness reasoning. See note 90 supra.

97 Three Justices maintained that the constitutional protection of free speech and press gave the defendants an absolute privilege to criticize public officials. $376 \mathrm{U}$ U.S. at 293-97 (Black, J., concurring, joined by Douglas, J.) ; id. at 297-305 (Goldberg, J., concurring, joined by Douglas, J.). In the interest of fully preserving first amendment rights, they are willing to immunize certain defamation even when uttered with malice.

It has been suggested that Sullivan actually has all but rejected a balancing test and is instead the first step toward the development of a broader theory of first amendment protection. Kalven, The Nere York Times Case: A Note on "The Central Meaning of the First Amendment," in 1964 The SUPREME CoURT RevIEW 191, 214-17 (Kurland ed. 1964). 
The analysis in Sullivan may also be applicable to a civil suit against demonstrators. Recovery is scarcely a paramount state interest. The balancing process dictates that, unless the package of deterrents can be decreased, civil suits for police costs should not be permitted.

The initial step toward decreasing the deterrent impact would consist of a requirement that the state demonstrate under criminal trial standards that defendants acted unlawfully. Where the demonstrator is faced with a criminal sanction or cost-taxing statute that requires criminal trial and conviction, he will be protected by procedural standards, including the necessity for the state to prove guilt beyond a reasonable doubt. The Supreme Court in Sullivan demonstrated sensitivity to the difficulties inherent in the potential infliction of large judgments that are deterrent in nature without giving the defendant the usual protections of the criminal trial..$^{98}$ But the solution which the Court utilized in Sullivan was to change the rule of law, not give further procedural protection, in effect determining that regardless of the procedural rules, the actual malice requirement would sufficiently limit the deterrence. ${ }^{99}$ This reasoning indicates that there would be no constitutional necessity to provide the protections of criminal trial in a suit to recover police costs. Without those protections, however, the deterrence potential increases, perhaps to the point where it becomes necessary to bar recovery from demonstrators. To reduce the risk that the recovery statute will be declared unconstitutional the state should require either a criminal conviction as a prerequisite to initiation of the civil suit or that the demonstrators' "guilt" be determined under criminal standards. ${ }^{100}$

Further reduction of the deterrence potential may be necessary. Protection must be given so that imprecise definitions of the extent of first amendment rights and the scope of unlawful conduct will not permit the state to collect a judgment on perhaps questionable facts beyond the scope of review. This problem has of course been faced where vagueness of criminal statutes has created unjustifiable limitations on the use of first amendment rights, prompting the Court to reverse convictions regardless of whether the conduct of the defendants was lawful, simply because the statutory form was vague ${ }^{101}$ or overly broad. ${ }^{102}$

98 See 376 U.S. at 277.

99 Compare Garrison v. Louisiana, 379 U.S. 64 (1964) (Sullivan rule applied in prosecution for criminal libel).

100 If a conviction is required, to provide adequate protection the conviction should necessarily be in a court of record. See also note 109 infra. As to the vagaries of justice that may result in trials held before tribunals that are not courts of record, see, e.g., Magistrates' Courts in Operation: The Philadelphia Story, in LIFE OF THE LAw 220-35 (Honnold ed. 1964).

101 See, e.g., Edwards v. South Carolina, 372 U.S. 229 (1963). Compare Lanzetta v. New Jersey, 306 U.S. 451 (1939).

102 See, e.g., Thornhill v. Alabama, 310 U.S. 88 (1940). 
This insulation, of course, does not mean that the activity is untouchable by the state. Often, by fastening upon incidents of it other than those to which the voided law attached or upon those same incidents plus others, the state may bring it under control ....103

The protection granted in the vagueness cases is only one step. Problems of proof will remain in any case, ${ }^{104}$ and can never be completely eliminated. Connected is the problem that vagueness can never be completely eliminated from a statute, coupled with the fact that the review function becomes more difficult as the vagueness of the statute increases. ${ }^{105}$ If the state is to recover police costs from demonstrators adjudged to have acted unlawfully, it is necessary for the courts to consider the statute defining the unlawful act not in isolation but in terms of the magnitude of deterrence and constitutional danger that it carries, ${ }^{106}$ balanced against the relatively minor state interest in cost recovery. ${ }^{107}$

The task of the Court in the police expense recovery cases must therefore be to weigh not only the deterrent effect of the criminal statute itself, but also to consider the added deterrent potential of indefinite expense recovery as balanced against the state's limited interest. The added factor of the civil suit indicates that the definition of the offense to which expenses attach ${ }^{108}$ must be a particularly narrow one; thus a statute that might be constitutionally valid for the application of a small penalty could at the same time be unconstitutionally vague when used in conjunction with a civil suit. ${ }^{109}$ The analysis must turn "not merely upon narrow questions as to the naked comprehensibility of a statutory phrase, but upon the entire context of the

103 Note, 109 U. PA. L. Rev. 67, 110 (1960).

104 Id. at $80 \mathrm{n} .72$. In addition, it is quite possible that the confusion of a large and rowdy demonstration may create perhaps unintentionally inaccurate testimony by police.

$105 \mathrm{Id}$. at 80 .

${ }^{106} C f$. id. at 89-96.

107 Id. at 89 :

[T] he high Court should stand, under the Constitution, as the final arbiter between the competing wills and needs of the whole people (represented in its legislatures) and of the individual. . . . But if the system is to remain viable, the restriction of procedures $\therefore$ must not be so rigorous as to prevent ... legislatures from effectuating a substantive end not constitutionally denied them, by . . . permissible means ...

108 It would not be necessary for the authorization of civil suit (or cost taxation) to be contained in each criminal statute. The legislature would most likely enact a measure giving general authorization to bring suit. The court should regard this legislation as attaching to each criminal statute.

109 Thus a defendant who might be convicted in a criminal trial could prevail in a civil suit for police recovery based on the same facts; if defendant is criminally convicted, he still might be able to have the statute under which the conviction resulted declared unconstitutionally vague when used for the civil recovery. While this may not make for symmetry, it can control the deterrent potential of cost recovery, for the demonstrator will know that if a suit is brought, the state will have to meet a higher standard of statutory definition. 
regulation attempted . . . "110 By requiring greater specificity in the statutory standard where a civil suit is involved, the Court can take at least one step toward saving first amendment rights from undue deterrence, and can maintain a balance in which both state and individual interests can survive.

Further protection is necessary aimed at limiting the extent of liability of demonstrators for others in the march, where all can legitimately be said to be acting "unlawfully." The usual doctrines of conspiracy and aider-and-abettor impose broad liability on the participants in an enterprise which is unlawful. ${ }^{111}$ But in a demonstration there may be differing relevant degrees of unlawful conduct, with differing consequences..$^{12}$ To minimize resulting deterrence, proof of a causal relation between the demonstrator's unlawful conduct and the amount of damages claimed should be necessary. ${ }^{113}$ Similar reasoning dictates that demonstrators should not be liable for the conduct of bystanders. ${ }^{114}$

If the foregoing suggestions successfully limit civil liability to those who actually have acted unlawfully, and keep recovery within causal bounds, the deterrent effect on first amendment rights will be limited. In that case, recovery from unlawful demonstrators would be constitutionally permissible.

\section{The Precarious ${ }^{115}$ Liability Problem}

Even if the deterrent effect on the individual is controlled, protection is not complete unless further assurance is given to the organizers of the demonstrations that liability for unlawful acts will not stretch too far. To achieve this end, the usual extent-of-liability rules will have to be modified when police expense recovery is aimed at demonstrators.

The problem arises because it will frequently be desirable to hold liable not only the individual demonstrators, ${ }^{116}$ but also the civil

$110 I d$. at 95-96.

111 See cases collected in Michaer \& Wechsler, Criminal Law and Its AdMINISTRATION 649-64, 667-71, 688-744 (1940); cf. note 124 infra.

112 The demonstrator who jaywalks, for example, will clearly cause less damage than the demonstrator who destroys a building with a molotov cocktail, and he will probably create less police expense as well.

113 In a sense, this rule combines aspects of evidentiary due process rules, see Garner v. Louisiana, 368 U.S. 157, 170-71 (1961); cf. Tot v. United States, 319 U.S. 463 (1943), with first amendment deterrence theories.

114 Cf. note 136 infra and accompanying text.

115 The term is used to connote the danger of applying usual concepts of vicarious liability in situations where the application would operate to suppress the use of constitutionally protected rights.

116 This is especially true if the aim is a financial one, for it may often be necessary to go beyond the demonstrators themselves to satisfy a judgment. If discouraging the demonstration is the purpose, it is obvious that discouraging the leaders from organizing a demonstration will go a long way toward preventing demonstrations from occurring. 
rights leadership, both organizations and individuals. ${ }^{117}$ The key questions will be: whether the leaders of a civil rights demonstration can be held liable for the illegal conduct of demonstrators when that conduct is unauthorized by the leadership who, although organizing the demonstration, intended a wholly lawful one; and whether the leadership can be held liable for the unlawful conduct of bystanders who are attracted by the demonstration.

These issues are presented in NAACP v. Overstreet, ${ }^{118}$ where local leaders of the NAACP organized demonstrations and boycotts against a white grocer who was accused of beating a fourteen-year-old Negro employee. During the picketing, various illegal acts occurred, although it does not seem to have been established that the picketers were responsible for them. ${ }^{119}$ Nonetheless, the Georgia court held the demonstrators liable for the damage to the grocer's business, ${ }^{120}$ and further held that the national organization of the NAACP was liable because of the "agency" of the local leaders. ${ }^{121}$ The Supreme Court granted certiorari only on the question of the national organization's liability, ${ }^{122}$ but dismissed the writ as improvidently granted. ${ }^{123}$

The potential difficulties created for civil rights groups by this decision are similar to the obstacles which faced organized labor in its earlier days. ${ }^{124}$ Section 6 of the Norris-LaGuardia

117 See NAACP v. Overstreet, 221 Ga. 16, 142 S.E.2d 816 (1965), cert. dismissed as improvidently granted, 384 U.S. 118 (1966).

118 Ibid.

119 Id. at $25-26,142$ S.E.2d at 825 .

120 The court grounded its decision on the theory that an illegal conspiracy existed because the demonstrations were employed for an illegal purpose: punishment of a crime (assault and battery on the boy), the proper place for which was in the courts. Since the store had a large Negro clientele, the court reasoned that there could not be a justifiable protest of discrimination-the beating, according to the court, did not occur because of the boy's race but rather stemmed from the grocer's belief that the youth had stolen from the store. It would seem that the courts ruling that the picketers would be liable for damage caused by bystanders who were incited by the picketing would have to be based on this finding that the demonstration was unlawful (even if peaceful). See notes 69-79 supra and accompanying text. A finding of this nature should not be available in most cases. And even where it is, its soundness is questionable. See note 136 infra.

121 The court found an agency relationship because the local NAACP chapter was "within the framework of the national organization," and because dues payments and attendance at national conventions, etc. demonstrated that the locals "are used in furtherance of the [national's] . . . business and interest." $221 \mathrm{Ga}$. at 27, 142 S.E.2d at 826 . From this, the court reasoned that the local leaders had acted within the scope of their authority, and that the national organization, by not disavowing the acts, had ratified them.

122382 U.S. 937 (1965).

123384 U.S. 118 (1966).

124 See NAACP v. Overstreet, 384 U.S. 118, 124 (1966) (Douglas, J., dissenting). Courts made it quite clear that labor organizations would be held liable for strike damage, regardless of their own good conduct: "[T] $T$ he authority is put $\therefore$ in their officers to order a strike, and if in the conduct of that strike unlawful injuries are inflicted, the District organization is responsible . . . UMW v. Coronado Coal Co., 259 U.S. 344, 403 (1922) (dictum). "[W] hen any number of persons associate themselves together in the prosecution of a common plan or enterprise, lazeful or unlazeful, from the very act of association there arises a kind of partnership. . . so that the act or declaration of one, in furtherance of the common object, is the act 
Act ${ }^{125}$ was designed to ameliorate this situation. ${ }^{126}$ "We have of course no like statute here. But the First Amendment, which commands vigilance lest the rights it assures be denied the "breathing space' . . . necessary for survival, provides guidance." ${ }^{127}$

There can be no doubt that liability of the type assessed in Overstreet can work to deter the use of first amendment freedomsin effect, to rob them of their "breathing space." If the NAACP, or an individual civil rights leader, knows that, although an entirely peaceful demonstration has been organized, a large judgment may be collected because of the police expenses created by illegal acts of demonstrators (and perhaps even bystanders) over whom effective control cannot be exerted, reluctance to organize the demonstration will ensue. It is precisely this potential reluctance that must be avoided if first amendment freedoms are to flourish. ${ }^{128}$ The state cannot constitutionally collect police expenses from the lawful demonstrator; in a search for a financially responsible defendant it should not be able to recover from an organization promoting a demonstration lawful at its inception.

True, to determine the scope of first amendment rights it is necessary to strike a balance at times with a broader public interest; ${ }^{129}$ but it seems that the deterrence here is great, while the public interest in the recovery of police expenses from the organization or its leaders

of all ...." Hitchman Coal \& Coke Co. v. Mitchell, 245 U.S. 229, 249 (1917). (Emphasis added.) See Franklin Union v. People, 220 I1l. $355,376-77,77$ N.E. 176, 183-84 (1906); United Traction Co. v. Droogan, 115 Misc. 672, 675-76, 189 N.Y. Supp. 39, 41-42 (Sup. Ct. 1921).

12547 Stat. 71 (1932), 29 U.S.C. $\$ 106$ (1964). The act states:

No officer or member of any association or organization, and no association or organization participating or interested in a labor dispute, shall be held responsible or liable in any court of the United States for the unlawful acts of individual officers, members, or agents, except upon clear proof of actual participation in, or actual authorization of, such acts, or of ratification of such acts after actial knozeledge thereof.

(Emphasis added.)

126 Under the Norris-LaGuardia Act and similar state statutes, courts have been a good deal more reluctant to find liability. See, e.g., UMW v. Gibbs, 383 U.S. 715 (1966); United Bhd. of Carpenters v. United States, 330 U.S. 395 (1947); Benoit v. Amalgamated Local 299, United Elec. Workers, 150 Conn. 266, 188 A.2d 499 (1963). 127 NAACP v. Overstreet, 384 U.S. 118, 125 (1966) (Douglas, J., dissenting). 128 To equate the liability of the national organization with that of the Branch in the absence of any proof that the national authorized or ratified the misconduct in question could ultimately destroy it. The rights of political association are fragile enough without adding the additional threat of destruction by lawsuit. We have not been slow to recognize that the protection of the First Amendment bars subtle as well as obvious devices by which political association might be stifled .... That the threat comes in the form of civil suits for damages . . . is of no consequence... Juries hostile to the aims of an organization in the educational or political fieid, unless carefully confined by meticulous instructions and judicial supervision, can deliver crushing verdicts that may stifle organized dissent from the views and policies accepted by the majority.

Id. at 122-23 (Douglas, J., dissenting).

129 See note 65 supra. 
is not of the overwhelming importance requisite ${ }^{130}$ for the subordination of constitutionally protected rights. ${ }^{131}$

The Sullivan reasoning ${ }^{132}$ is again relevant. A state has an interest sufficient, under the ordinary rules of agency and conspiracy: ${ }^{133}$ to extend liability to the organizer of an enterprise. But when the enterprise organized is a peaceful and protected demonstration that becomes unlawful by accident, a different rule is necessary. In Sullivan, the Court found it necessary to alter the common law rules of defamation to fit them into the first amendment context; similar constitutional policies dictate a new rule here. It is clear that the fear of liability resulting from uncontrollable events might well discourage promotion of protected lawful gatherings. Although lawful gatherings might become unlawful, and although the state does have a right to limit unlawful conduct, that right does not go so far as to permit the suppression of all demonstrations to make sure that none can become unlawful. Permitting liability for subsequent and uncontrollable lawlessness to attach to the organizer of the lawful demonstration does exactly that. It is a clear case of throwing out the first amendment "baby" with the unlawful conduct "bathwater"; this type of all-inclusive control violates the reasoning of Sullivan and of the vagueness analysis. ${ }^{134}$ A rule that holds liable only those leaders or organizations who intend ${ }^{135}$ unlawful conduct to be the result of a demonstration is necessary to protect first amendment freedoms.

Likewise, the conduct of bystanders should not subject the leaders to liability unless there is intent to incite the bystanders to commit unlawful acts. "[T] he possibility of disorder by others cannot justify

130 See note 66 supra.

131 In Overstreet, the opposing interest was recovery by a private individual, and it is arguable that such an interest deserves greater deference than a state attempt to recover for police expenses. However, the fact that a private interest is involved does not mean that deterrence is always permissible. See New York Times Co. v. Sullivan, 376 U.S. 254 (1964). While perhaps the individual should have wider latitude than the state in recovering from individual rioters, his interest does not seem sufficient to permit recovery from nonrioting leaders, and while the subsequent textual discussion is essentially directed at the validity of recovery of police expenses by the state, its reasoning should apply to private individuals as well. "When we balance the Constitutional rights of owners of property against those of the people to enjoy [first amendment rights] . . . we remain mindful of the fact that the latter occupy a preferred position." Marsh v. Alabama, 326 U.S. 501, 509 (1946).

132 See notes 93-97 supra and accompanying text.

138 These rules were those applied in the early, common law labor cases. See note 124 supra.

134 See notes 101-03 supra and accompanying text.

135 The rule of intent will have to be a strict one. Clear showing of inciting or authorizing illegal acts should be necessary. The leaders of the demonstrations should not be obliged to watch carefully their language so that no statement can be construed by a hostile court as incitement or authorization. Cf. Thomas v. Collins, 323 U.S. 516 (1945). Similarly, liability should not be fastened on the leadership because of "negligent" organization, although perhaps liability for "wilful, wanton misconduct" would be permissible. Compare the Court's opinion in Sullivan werth the concurring opinions in that case, discussed at note 97 supra. 
exclusion of persons from a place if they otherwise have a constitutional right . . . to be present." ${ }^{136}$

\section{CONCLUSION}

Although a legislature could enact a statute permitting recovery of police expenses from convicted ${ }^{137}$ criminals, the statute would be of limited utility in an attempt to control civil rights demonstrations. Such a measure must be both drafted and enforced in a nondiscriminatory manner, or it would likely be voided on equal protection grounds. Furthermore, when applied to civil rights demonstrators, it could be directed only at those who engage in or intend to promote unlawful conduct. The increased degree of deterrence created by a cost statute or civil suit necessitates a much stricter definitional standard to withstand vagueness analysis. Thus the statute would no more than supplement existing criminal sanctions. Clearly, then, the statute would, and should, have limited impact in discouraging civil rights advocates from demonstrating peacefully. Its main effect would be the addition of a new function-the recovery of police expense-to the general law of cost taxation. ${ }^{138}$

136 Wright v. Georgia, 373 U.S. 284, 293 (1963). But cf. Feiner v. New York, 340 U.S. 315 (1951). The fact that a court may find, as in Overstreet, that the peaceful demonstration was for an "unlawful" (tortious) purpose, see note 120 supra, should not subject the leadership to liability for either bystanders' misconduct or the unplanned misconduct of the demonstrators, unless the unlawful purpose was one that was likely to cause disorder. In one situation, however, the leadership should perhaps be liable for an "unlawful" but nonriotous demonstration. Groups may demonstrate with the avowed purpose of causing such a great police expense that the local authorities will, in effect, be blackmailed into giving concessions. See, e.g., the following statement made by Cecil Moore, head of the Philadelphia chapter of the NAACP. "We're prepared to cost the city another million dollars in overtime for the police, and to keep the issue alive . .." Philadelphia Evening Bulletin, Aug. 27,1966 , p. 3 , col. 5 . A demonstration of this type is perhaps not deserving of the same protection as is a legitimate use of free expression. On the other hand, it will probably be rare for a demonstration to be directed only at creating police expense; usually there will be a legitimate protest involved as well, and under those circumstances it would be unwise to give the expression a lesser standard of protection.

137 But see text accompanying notes 88-89 supra.

138 Whether recovery for police expenses should be allowed is a problem for legislative resolution. Various policy considerations might dictate a negative answer (this might seem to be the case to a southern legislator if the statute will be of limited utility in the civil rights area), but the question is beyond the scope of this Comment. 